\title{
Contribution of Laser-nduced Gas-Vapor-Liquid Dynamics to the Mechanism of Endovenous Laser Ablation
}

D01. $10,17691 / \mathrm{stm} 2016,8.2 .01$

Received October 26, 2015

V.M. Chudnovskii, DSc, Head of the Laboratory of Biophysics';

VI. Yusupov, PhD, Senior Researcher, Laboratory of Acoustical Oceanography';

Senior Researcher, Laboratory of Laser Nanomodification of Materials';

O.L. Zakharkina, Researcher, Department of Perspective Laser Technologies;

N.Yu. Ignatieva, DSc, Associate Professor, Faculty of Chemestry4;

V.S. Zhigarkov, Student, Faculty of Experimental and Theoretical Physics;

M.N. Yashkin, MD, PhD, Interventional Phlebologist ${ }^{6}$;

V.N. Bagratashvili, DSc, Professor, Head of the Department of Laser Atomic and Molecular Technologies ${ }^{3}$

'V.I. Ilyichev Pacific Oceanological Institute, Far Eastern Branch of the Russian Academy of Sciences, 43 Baltiyskaya St., Vladivostok, 690041, Russian Federation;

2Institute of Applied Physics, Russian Academy of Sciences, 46 Ulyanova St., Nizhny Novgorod, 603950,

Russian Federation;

${ }^{3}$ Institute of Laser and Information Technologies, Russian Academy of Sciences, 2 Pionerskaya St., Moscow,

Troitsk, 142190, Russian Federation;

${ }^{4}$ Lomonosov Moscow State University, 1, Bldg. 3 Leninskiye Gory, Moscow, 119991, Russian Federation;

${ }^{5}$ National Research Nuclear University MEPhl (Moscow Engineering Physics Institute), 3 Kashirskoe Shosse,

Moscow, 115409, Russian Federation;

${ }^{6}$ National Medical Surgical Centre named after N.I. Pirogov, 70 Nizhnyaya Pervomayskaya St., Moscow, 105203,

Russian Federation

The aim of the investigation is to ground experimentally the mechanism of endovenous laser ablation (EVLA), based on laser-induced convective heat transfer from the blood to the vein walls due to its boiling as a dominating process in a complicated mechanism of heat exchange occurring in endovasal laser manipulations.

Materials and Methods. In experimental modeling of EVLA, fragments of varicose trunks of great suphenous veins, removed by combined phlebectomy, have been used. Laser radiation with $970 \mathrm{~nm}$ wavelength and 6 and $7 \mathrm{~W}$ power was delivered into the vein through a quartz optical fiber with a flat preblackened (initiated) tip. Pullback velocity was $0.5 \mathrm{~mm} / \mathrm{s}$. The surface temperature of the vein was measured during laser radiation using FLIR A600 (Sweden) infrared camera. Denaturation of collagen in the vein wall caused by laser impact was determined by differential scanning calorimetry.

Results. Recording the surface temperature dynamics of vein with infrared camera allowed visualization of spot heating of the vein wall by the fluid surrounding the gas-steam bubbles. Temperature saturation in the dynamics of heating the media under study has been established to exist, being one of the characteristic features of the first-order phase transition. The degree of collagen denaturation in the venous wall specimens at 6 and $7 W$ amounted to $87 \pm 5$ and $97 \pm 3 \%$, respectively.

Conclusion. Bubble boiling of blood in the veins, providing fast and efficient heat transfer from the heated tip of the quartz optical fiber to the vein walls, has been experimentally confirmed. For successful performing of the EVLA, the fiber traction must be started at the moment of blood boiling; at lower laser powers the fiber must be held for a longer period. In clinical EVLA procedures less powerful and safer laser devices can be used, reducing the risk of post-treatment complications.

Key words: endovenous laser ablation; coagulation of venous blood; blackened tip; laser-induced hydrodynamics; convective heat transfer; mechanism of action.

For contacts: Vladimir I. Yusupov, e-mail: iouss@yandex.ru 
Endovenous laser ablation, EVLA (coagulation, ablation), including great suphenous vein, is a safe, low-traumatic and effective surgical method of varicose disease treatment. In recent time it occupies a leading position among other surgical methods. Since its first application in 1999 [1] the physical mechanism of EVLA, which could be the basis of developing a unified approach to the choice of the mode, exposure and wavelength of laser radiation, has remained controversial.

Application of endovenous laser radiation in surgical practice is based on transformation of laser radiation into heat, which is delivered by means of heat exchange to the pathologically changed venous walls. For successful obliteration of the vessel irreversible denaturation of the collagen, forming the framework of the venous wall, must take place. Therefore, the attainable temperature of the venous wall should exceed that of the denaturation of the main tissue structural protein [2].

Three types of heat transfer are known to exist heat conduction, convection (mixing) and radiation [3]. Accordingly, various ways of delivery of laser radiation, transformed into heat, to venous walls are considered. These techniques determine in many respects physical mechanisms of EVLA.

Conductive heat transfer requires direct contact of the heat carrier with intima - internal layer of the vein interacting with blood. In early studies venous wall was supposed to be heated due to the contact of steam bubbles, generated by laser radiation, with the intima [4]. Later, condensation of steam with heat release, and the supposition that vein warms up according to the operating principle of a heat-pipe, were added to this mechanism $[5,6]$.

This concept has prevailed long enough in the minds of clinicians, till doubts appeared relative to its physical consistency. Steam bubbles cannot significantly heat a venous wall, as the density of saturated vapor at the atmospheric pressure even at $100^{\circ} \mathrm{C}$ is only $6 \cdot 10^{-4}$ of the water density, while the similarity with a heat-pipe is not correct because bubbles contain not only water vapors but some other gases as well [7-9].

As to the radiation heat transfer, a large number of investigations have been carried out to study the effect of radiation wavelength on the EVLA efficacy. The first in this procedure were lasers with the wavelengths in the range of $0.75-1.06 \mu \mathrm{m}$, falling into the absorption band of oxy-and deoxyhemoglobin [10]. This group of lasers was called hemoglobin absorbing lasers [4, 11-13]. Later, lasers with the emission in the region of water absorption peaks (1.32-1.56 $\mu \mathrm{m}$ band) found their application. In connection with EVLA these lasers were named water absorbing [14-16]. Radiation of water absorbing lasers is considered to reach readily a venous wall without being absorbed by blood cells - erythrocytes, whereas hemoglobin absorbing lasers affect originally only erythrocytes, initiating thrombus formation. A venous wall warms up as a result of complicated conductive and radiation heat exchange between the thrombi, heated by radiation, and surroundings. This idea was subjected to criticism because erythrocytes are by 65 $70 \%$ composed of water [7]. Eventually, the differences in clinical efficacy of water absorbing and hemoglobin absorbing lasers appeared to be insignificant, important are methodological approaches to conduction of these procedures by various authors $[7,8,17]$.

In some studies $[8,18,19]$ attention has been paid to the fact, that in the process of laser radiation, the fiber tip contacting the blood, is covered by a layer of carbon (becomes black). As almost an absolutely blackbody this working tip absorbs laser radiation of any wavelength and is heated up to $1,000^{\circ} \mathrm{C}$ or higher [20-25]. And therefore such a hot tip becomes a source of a power thermal radiation (Plank's radiation law), which can heat venous walls directly and is thought by some authors [8] to specify a physical mechanism of EVLA. Such heating is prevented by the water, absorbing thermal radiation, which surrounds the optical fiber tip. In this connection, some researchers suggest using laser radiation of greater power (about $20 \mathrm{~W}$ ), which must "dry" the adjacent area. But at large powers serious complications are observed [26, 27]: venous wall perforation, periphlebitis, hematomas and paresthesias.

Artificial blackening of the fiber end - deposition of a carbon layer to its surface - to create a spot heat source, warmed up to high temperatures (100-600 $\mu \mathrm{m}$ diameter of optical fiber quartz strand), is widely used in surgical practice. A laser knife for contact dissection of water-saturated biological tissues works just according to this principle $[23,24]$. A blackened end is used in puncture operations for treatment of disk hernias [28, 29], true cysts [30] and so on. It is important to note, that a strong warming up of a blackened fiber area is reached at low laser radiation powers, i.e. already at $\sim 0.5-1.0 \mathrm{~W}$ [23].

A high temperature fiber tip inserted to the vein contacts the blood (water dispersion), resulting in its burst boiling and exothermal oxidation of organic components [21, 23]. These processes initiate flows of hot blood with the following convective heat transfer to venous walls. It is simple enough to provide blood boiling nearby the blackened tip just at a moderate power (1-7 W) of laser radiation with any wavelength [23, 31].

To substantiate the EVLA mechanism it is necessary to register in dynamics the effect of heated fluid flows on the venous wall. Investigations of thermal flow distributions in the vein using spot thermocouples $[2,17]$ allow only rough estimation of temperature distribution on the venous wall and do not take into consideration dynamics of heating. This task needed to clarify the EVLA mechanism can be solved with the help of stateof-the-art high-speed highly sensitive infrared camera, which has been used in the given work. 
The aim of investigation is to ground experimentally the mechanism of endovenous laser ablation, based on laser-induced convective heat transfer from the blood to the vein walls due to its boiling as a dominating process in a complicated mechanism of heat exchange occurring in endovasal laser manipulations.

Materials and Methods. For EVLA modeling varicose-changed trunks of greater saphenous veins, removed by combined phlebectomy (4 patients, average age $-51.6 \pm 7.8$ years, C2 clinical class of the disease according to CEAP classification) have been used. The trunks were stored in $0.15 \mathrm{M}$ solution of $\mathrm{NaCl}$ at $4-8^{\circ} \mathrm{C}$ not longer than $8 \mathrm{~h}$ before the beginning of the experiment. Each trunk was separated into fragments of $50 \pm 5 \mathrm{~mm}$ long, the average diameter being $5.4 \pm 1.6 \mathrm{~mm}$. 15 fragments were used in the experiment.

The ends of the veins were contracted 1-2 mm from the margins in order to reduce the inner diameter to $\sim 1 \mathrm{~mm}$ retaining the opening section as close to the circular form as possible. Then the ends were fixed with a weak tension to a plastic substrate, having a triangular profile, with one side left open. About $0.5 \mathrm{ml}$ of heparinized blood were introduced from both ends into the vein and distributed evenly along it. Quartz optical fiber with a flat, preliminary blackened end and $600 \mu \mathrm{m}$ diameter was inserted from the distal end inside the vein fragment. The whole construction was placed horizontally in the $11 \times 70 \mathrm{~mm}$ container filled with $0.15 \mathrm{M}$ solution of $\mathrm{NaCl}$. A stripe of vein with $\sim 1 \mathrm{~mm}$ width projected from the solution surface, which allowed registration of thermal radiation intensity from the venous wall surface. Registration of temperature field dynamics was carried out using infrared thermograph FLIR A600 (Sweden) with $8 \mathrm{~ms}$ sensor time constant and recording speed of 50 frames per second.

LS-0.97 (IRE-Polus, Russia) semiconductor laser with $0.97 \mu \mathrm{m}$ wavelength and $11 \mathrm{~W}$ maximal power was used in the experiment. Radiation power was controlled with UP12-H (Gentec Electro-Optics, Canada) power meter. Traction of the optic fiber in the vessel was done in the automatic mode with a device-preset velocity of $0.5 \mathrm{~mm} / \mathrm{s}$.

After laser exposure specimens from the middle part of the fragment were analyzed using differential scanning calorimetry. Preparations with 7-10 mg mass were closed hermetically in standard aluminum containers $(20 \mu \mathrm{l})$ and heated in the cell of DSC204F (Netzch, Germany) calorimeter from a room temperature to $85^{\circ} \mathrm{C}$ with a rate of $10^{\circ} \mathrm{K} / \mathrm{min}$. An empty container served as a reference. Denaturation enthalpy $(\Delta \mathrm{Hd})$ was calculated relative to a dry preparation residue.

Quantitative results were statistically processed using Student's t-criterion, mean and standard deviation. Preliminarily, the analysis of compared samples on the compliance with the normal law of distribution was conducted. Differences were statistically significant at $p<0.001$. Mean values and standard error of the mean $(\mathrm{M} \pm \mathrm{m})$ were calculated.
Results. With the help of IR-thermograph a typical image of $\mathrm{NaCl}$ solution surface with the vein in the container has been obtained (Figure 1). A heated region of protruding venous wall stripe is distinguished. In the hottest area, corresponding to the position of the fiber tip, thermal projections of steam-gas bubbles are clearly visualized. On Figure 2 examples of time evolution of maximal temperature on the external surface of the venous wall during fiber movement are given for laser radiation power of 6 and $7 \mathrm{~W}$. Maximal temperaturetime relation is represented by a curve with saturation. The saturation began about $7 \mathrm{~s}$ after the laser switching on, when temperature reached $70-80^{\circ} \mathrm{C}$, and the fiber moved over a distance of $\sim 3.5 \mathrm{~mm}$. Curve 1 , obtained using $7 \mathrm{~W}$ laser radiation in the period from 0 to $9 \mathrm{~s}$ appeared unexpectedly to lie lower than curve 2, obtained with the help of $6 \mathrm{~W}$ laser. For example, for the time $5.0 \pm 0.2 \mathrm{~s}$ the temperature for $6 \mathrm{~W}$ was $\mathrm{T}_{6}=68.5 \pm 0.5^{\circ} \mathrm{C}$, while for $7 \mathrm{~W}$ it was $\mathrm{T}_{7}=64.7 \pm 0.4^{\circ} \mathrm{C}$, the samples being statistically significantly different, $p=0.008$, i.e. lower rate of temperature rise corresponds to greater power. At a longer periods of time $(25 \pm 5 \mathrm{~s})$, as seen on Figure 2, the higher temperature corresponds to the greater laser radiation power: $\mathrm{T}_{6}=83.0 \pm 0.5^{\circ} \mathrm{C}$, while $\mathrm{T}_{7}=91.1 \pm 0.3^{\circ} \mathrm{C}$, at statistically significant difference of the samples, $p=0.002$.

A complicated profile of the curves on the saturation line should be noted. In particular, local maximums are observed when the temperature exceeds $90^{\circ} \mathrm{C}$, and minimums. It can be explained by active hydrodynamic processes, and also the influence (screening) of bubbles, emerging in blood boiling.

On Figure 3 thermograms of venous wall specimens obtained by differential scanning calorimetry are presented. Endothermal peak with a maximum of

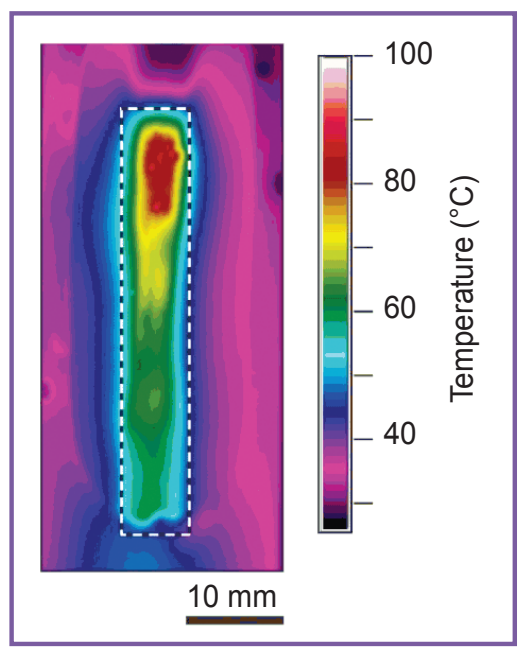

Figure 1. Temperature distribution over the vein fragment surface. Pullback velocity of laser fiber tip is $0.5 \mathrm{~mm} / \mathrm{s}$. Vein contours are outlined by a rectangle. Spot heating of the venous wall by the fluid, surrounding gas-steam bubbles, are seen 
$68.0 \pm 0.7^{\circ} \mathrm{C}$ associated with the absorption of heat in denaturation (helix-coil transition) of collagen macromolecules is observed [32] on the thermograms of intact preparations (curve 1). The peak area corresponds to enthalpy of denaturation $\Delta \mathrm{Hd}$, which amounts to $10 \pm 3 \mathrm{~J} / \mathrm{g}$ of the dry weight. After laser impact the peak area essentially reduces and may disappear completely (curves 2-4). The reduction of $\Delta \mathrm{H}$ transition enthalpy indicates to the decrease of the portion of intact macromolecules in the preparations due to laser exposure. The degree of a collagen denaturation was determined according to the ratio $\alpha=(1-\Delta H / \Delta H d) \cdot 100 \%$. For 6 and $7 \mathrm{~W}$ power the value of a was $87 \pm 5$ and $97 \pm 3$, respectively; $\Delta \mathrm{Hd}=-18.4 \mathrm{~mJ} / \mathrm{g}$ of the dry weight. Thus, actually full degradation of vessel wall collagen framework took place.

Discussion. Temperature characteristics of the processes, generated by laser radiation in the venous vessel filled with heparinized blood have been investigated in this work. It has been established, that laserinduced hydrodynamics in such a model, connected with blood boiling, provides convective heat transfer to the vessel walls and creates the necessary and sufficient conditions for successive performance of EVLA. The main condition is heating the venous wall to the temperatures at which irreversible denaturation of proteins, which are the part of its composition, occurs, and a sufficient condition is a complete degradation of tissue matrix framework [2].

Experimental results have proved, that preblackening of the fiber tip results in a rapid rise of the temperature of the external surface of the vessel wall up to $\sim 80-90^{\circ} \mathrm{C}$ (See Figure 2), which essentially exceeds the temperature of collagen denaturation in the tissues [33]. During the first $9 \mathrm{~s}$ the rate of temperature growth reduces with the increase of laser radiation power. It can be explained by the fact that with the increase of radiation power the volume of fluid involved in movement grows and more time is required for warming it up. When the period of time is longer (25-40 s), the temperature on the venous wall surface rises to higher values with power increase.

The next important result was temperature saturation in the dynamics of examined media heating (See Figure 2). It means, that when a vein filled with blood is heated by a laser, some mechanism of heat sink is triggered, which is weakly related to the power of the heat source; it is the rate of reaching the saturation temperature that depends on it. A similar result, i.e. reaching the temperature plateau in the experimental model of EVLA for $1,470 \mathrm{~nm}$ laser, is shown in the 
work [2]. However, the authors were solving a different task and did not discuss the obtained result, which in comparison with our data means, in particular, that the effect of blood boiling does not depend on the wavelength.

This conclusion is evident for a well-blackened fiber tip (which is done beforehand or in the course of the procedure), when a layer of carbon on the end of the optical fiber (as an absolute blackbody) will be heated by absorbing laser radiation of actually any wavelength.

Presence of the temperature plateau in the course of heating is one of the characteristic features of first-order phase transition [3]; in case of the system being discussed such transition is boiling. Boiling is a process of intensive transformation and convection, accompanied by moving of the fluid and vapor bubbles in the space. Bubble dynamics is caused by temperature gradients and, in fact, provides heat dissipation.

In the previous works [21, 22] it has been shown, that heated by laser radiation preblackened fiber tip generates bubbles of $10 \mu \mathrm{m}-0.5 \mathrm{~cm}$ dimension in the water, which are intensively moving (boiling bubbles). In this case linear speeds of small bubbles reach $100 \mathrm{~mm} / \mathrm{s}$. The associated mass of heated fluid, which for a spherical body amounts to half the fluid mass enclosed in the bubble volume, is involved in the bubble movement, and in case of boiling bubbles provides rapid and effective heat transfer to the vessel walls [3]. The trajectories of the bubbles in capillaries have a complicated shape of volute spiral and linear translations - submerged microjets [22, 23]. This laser-induced dynamics in the system "venous wall/ blood" is believed to result in wall heating by convective heat transfer from boiling blood to vein intima. Our conclusion is confirmed by clinical data, obtained during US-controlled EVLA operations. Clinicians note a veil of boiling bubbles in the venous vessel exposed to laser radiation during US-assisted operations, though associate this phenomenon with physically unconvincing mechanisms of vein heating $[6,34]$.

Thus a solution to a vital problem of modern phlebology has been found - a physical mechanism of endovenous laser ablation of varicose veins. In the previously suggested mechanisms laser-induced hydrodynamics and associated dynamics of gas-steam bubbles generated in the veins due to the contact of the quartz fiber tip, heated to the high temperatures $\left(\sim 1,000^{\circ} \mathrm{C}\right)$, with blood has not been considered.

Performed EVLA modeling has confirmed experimentally bubble boiling of the blood in the venous vessel, which provides rapid and effective teat transfer from the heated blood to venous walls. Temperature measurements have proved, that venous wall is quickly and effectively heated to the temperatures exceeding that of the irreversible denaturation of the main structural protein of the tissue matrix - collagen. Eventually, a reliable obliteration of the venous vessel has been provided. Besides, fiber blackening makes EVLA effective irrespective of laser radiation wavelength.

Since boiling is a threshold process, it will not occur if the power of laser radiation is less than the threshold one. Consequently, for successful performance of EVLA retraction of the fiber should be started from the moment of blood boiling. At lower powers of laser radiation the fiber should be retained for a longer time. It follows, that in clinical EVLA procedure less powerful, safer in terms of complications and, therefore, cheaper lasers can be used.

Conclusion. Bubble boiling of blood in the veins, providing fast and efficient heat transfer from the heated tip of the quartz optical fiber to the vein walls, has been experimentally confirmed. To perform EVLA successfully, the fiber traction must be started at the moment of blood boiling; at lower laser powers the fiber must be held for a longer period. In clinical EVLA procedures less powerful and safer laser devices, reducing the risk of complications can be used.

Study Funding and Conflicts of Interest. The work was supported by the Russian Scientific Fund (grant No.14-15-00840). The authors declare no conflicts of interest related to the present study.

\section{References}

1. Bone Salat $C$. Tratamiento endoluminal de las varices con láser de diodo. Estudio preliminar. Revista de Patología Vascular 1999; 5(1): 31-39.

2. Shevchenko lu.L., Stoiko lu.M., Mazaishvili K.V., Maksimov S.V., Tsypliashchuk A.V., Parikov M.A., Ignat'eva N.Iu., Zakharkina O.L. The choice of the optimal parameters of $1470 \mathrm{~nm}$ radiation for endovenous laser obliteration. Flebologiya 2013; 7(4): 18-24.

3. Kutateladze S.S. Osnovy teorii teploobmena [Fundamentals of heat transfer theory]. Moscow: Atomizdat; 1979; $416 \mathrm{p}$.

4. Proebstle T.M., Lehr H.A., Kargl A., Espinola-Klein C., Rother W., Bethge S., Knop J. Endovenous treatment of the greater saphenous vein with a 940-nm diode laser: thrombotic occlusion after endoluminal thermal damage by lasergenerated steam bubbles. J Vasc Surg 2002; 35(4): 729-736, http://dx.doi.org/10.1067/mva.2002.121132.

5. Proebstle T., Sandhofer M., Kargl A., Gül D., Rother W., Knop J., Lehr H.A. Thermal damage of the inner vein wall during endovenous laser treatment: key role of energy absorption by intravascular blood. Dermatol Surg 2002; 28(7): 596-600, http://dx.doi.org/10.1046/j.1524-4725.2002.01309.x.

6. van der Geld C.W., van den Bos R.R., van Ruijven P.W., Nijsten T., Neumann H.A., van Gemert M.J. The heat-pipe resembling action of boiling bubbles in endovenous laser ablation. Lasers Med Sci 2010; 25(6): 907-909, http://dx.doi. org/10.1007/s10103-010-0780-2.

7. Malskat W.S., Poluektova A.A., van der Geld C.W., Neumann H.A., Weiss R.A., Bruijninckx C.M., van Gemert M.J. Endovenous laser ablation (EVLA): a review of mechanisms, modeling outcomes, and issues for debate. Lasers Med Sci 2014; 29(2): 393-403, http://dx.doi.org/10.1007/s10103-0131480-5. 
8. Shevchenko lu.L., Stoiko lu.M., Mazaishvili K.V., Khlevtova T.V. Mechanism of endovasal laser obliteration: a novel view. Flebologiya 2011; 5(1): 46-50.

9. Zhilin K.M. Vliyanie dliny volny lazernogo izlucheniya blizhnego IK-diapazona na kharakter silovogo vozdeystviya na biologicheskie tkani (krov', venoznaya stenka, slizistaya obolochka i kostnaya tkan'). Avtoref dis. ... kand. fiz.-mat. nauk [Effect of the wavelength of near IR-range laser radiation to the character of force action on biological tissues (blood, venous wall, mucous membrane and bone tissue). PhD Thesis]. Moscow; 2013.

10. Roggan A., Friebel M., Dörschel K., Hahn A., Müller G. Optical properties of circulating human blood in the wavelength range 400-2500 nm. J Biomed Opt 1999; 4(1): 36-46, http:// dx.doi.org/10.1117/1.429919.

11. Proebstle T.M., Gül D., Kargl A., Knop J. Endovenous laser treatment of the lesser saphenous vein with a $940-\mathrm{nm}$ diode laser: early results. Dermatol Surg 2003; 29(4): 357-361, http://dx.doi.org/10.1046/j.1524-4725.2003.29085.x.

12. Oh C.K., Jung D.S., Jang H.S., Kwon K.S. Endovenous laser surgery of the incompetent greater saphenous vein with a 980-nm diode laser. Dermatol Surg 2003; 29(11): 1135-1140, http://dx.doi.org/10.1046/j.1524-4725.2003.29353.x.

13. Weiss R.A. Comparison of endovenous radiofrequency versus $810 \mathrm{~nm}$ diode laser occlusion of large veins in an animal model. Dermatol Surg 2002; 28(1): 56-61, http://dx.doi. org/10.1046/j.1524-4725.2002.01191.x.

14. Schwarz T., von Hodenberg E., Furtwängler C., Rastan A., Zeller T., Neumann F.J. Endovenous laser ablation of varicose veins with the 1470-nm diode laser. J Vasc Surg 2010; 51(6): 1474-1478, http://dx.doi.org/10.1016/j.jvs.2010.01.027.

15. Rathod J., Taori K., Joshi M., Mundhada R., Rewatkar A., Dhomane S., Gour P. Outcomes using a 1470-nm laser for symptomatic varicose veins. J Vasc Interv Radiol 2010; 21(12): 1835-1840, http://dx.doi.org/10.1016/j. jvir.2010.09.009.

16. Sokolov A.L., Liadov K.V., Lutsenko M.M., Lavrenko S.V., Liubimova A.A., Verbitskaya G.O., Minaev V.P. Endovascular laser ablation with wavelength $1.56 \mathrm{~nm}$ for varicose veins. Angiologiya i sosudistaya khirurgiya 2009; 15(1): 69-76.

17. Shaidakov E.V., lliukhin E.A., Petukhov A.V., Rosukhovskii D.A. Comparison of lasers emitting at 970 and $1470 \mathrm{~nm}$ wavelengths for the in vitro simulation of endovasal laser vein obliteration. Flebologiya 2011; 5(4): 23-30.

18. Amzayyb M., van den Bos R.R., Kodach V.M., de Bruin D.M., Nijsten T., Neumann H.A., van Gemert M.J. Carbonized blood deposited on fibres during 810, 940 and $1470 \mathrm{~nm}$ endovenous laser ablation: thickness and absorption by optical coherence tomography. Lasers Med Sci 2010; 25: 439-447, http://dx.doi.org/10.1007/s10103-009-0749-1.

19. Mordon S., Wassmer B., Servell P., Desmyttère J., Grard C., Stalnikiewicz G. Is a vein filled with blood a good model for studying endovenous laser ablation? Lasers Surg Med 2009; 41(8): 543-544, http://dx.doi.org/10.1002/ Ism.20809.

20. van den Bos R.R., Kockaert M.A., Martino Neumann H.A., Bremmer R.H., Nijsten T., van Gemert M.J. Heat conduction from the exceedingly hot fiber tip contributes to the endovenous laser ablation of varicose veins. Lasers Med Sci 2009; 24(2): 247-251, http://dx.doi.org/10.1007/s10103008-0639-y.

21. Yusupov V.I., Chudnovskii V.M., Bagratashvili V.N. Laser-induced hydrodynamics in water-saturated biotissues. 1. Generation of bubbles in liquid. Laser Phys 2010; 20(7): 1641-1647, http://dx.doi.org/10.1134/S1054660X1014001X.

22. Yusupov V.I., Chudnovskii V.M., Bagratashvili V.N. Laser-induced hydrodynamics in water-saturated biotissues: 2. Effect on delivery fiber. Laser Phys 2011; 21(7): 1230-1234, http://dx.doi.org/10.1134/S1054660X11140015.

23. Yusupov V.I., Chudnovskii V.M., Bagratashvili V.N. Laser-induced hydrodynamics in water and biotissues nearby optical fiber tip. In: Hydrodynamics - advanced topics. Schulz H.E. (editor). InTech; 2011; p. 95-118, http://dx.doi. org/10.5772/28517.

24. Chudnovskii V.M., Yusupov V.I. Punktsionnaya svetovodnaya igla (varianty) i ogranichitel' dlya nee [Puncture optical fiber needle (variants) and a limiter for it]. Patent PF 58904. 2006.

25. Shevchenko Yu.L., Stoyko Yu.M., Mazayshvili K.V. Lazernaya khirurgiya varikoznoy bolezni [Laser surgery of varicose disease]. Moscow: Borges; 2010.

26. Dexter D., Kabnick L., Berland T., Jacobowitz G., Lamparello P., Maldonado T., Mussa F., Rockman C., Sadek M., Giammaria L.E., Adelman M. Complications of endovenous lasers. Phlebology 2012; 27(Suppl 1): 40-45, http://dx.doi.org/10.1258/phleb.2012.012S18.

27. Dunst K.M., Huemer G.M., Wayand W., Shamiyeh A. Diffuse phlegmonous phlebitis after endovenous laser treatment of the greater saphenous vein. J Vasc Surg 2006; 43(5): 1056-1058, http://dx.doi.org/10.1016/j.jvs.2006.01.030.

28. Chudnovskyi V., Bulanov V., Jusypov V. Laser induction of acoustic hydrodynamical effects in medicine. Fotonika 2010; 1: 30-36.

29. Chudnovsky V.M., Yusupov V.I., Machovskaya T.G. Laser-induced acustohydrodynamic effects in surgery of disc hernia. Vestnik nevrologii, psikhiatrii i neyrokhirurgii 2013; 4: 76-82.

30. Kuchareva L.I., Nevouzhai V.I., Chudnovsky V.M. Tltrasonography in diagnostics and sclerotizing therapy of cyst formation of the breasts. Dal'nevostochnyy meditsinskiy zhurnal 2008; 3: 49-51.

31. Yusupov V.I., Bulanov V.V., Chudnovskii V.M., Bagratashvili V.N. Laser-induced hydrodynamics in watersaturated tissue: III. Optoacoustic effects. Laser Phys 2014, 24(1), http://dx.doi.org/10.1088/1054-660X/24/1/015601.

32. Willett T.L., Labow R.S., Lee J.M. Mechanical overload decreases the thermal stability of collagen in an in vitro tensile overload tendon model. J Orthop Res 2008; 26 (12): 16051610, http://dx.doi.org/10.1002/jor.20672.

33. Ignat'eva N.Yu. Termicheskaya stabil'nost' kollagena $v$ soedinitel'nykh tkanyakh. Avtoref dis ... dokt. khim. nauk [Thermal stability of collagen in connective tissues. PhD Thesis]. Moscow; 2011.

34. van der Geld C.W.M. The dynamics of a boiling bubble before and after detachment. Heat Mass Transf 2009; 45(7): 831-846, http:Hdx.doi.org/10.1007/s00231-007-0254-7. 